\title{
Physical composition of carcass, commercial cuts and meat characteristics of crossbred Holstein-Zebu young bulls fed crude glycerin levels in the diets ${ }^{1}$
}

\section{Composição física da carcaça, cortes comerciais e características da carne de tourinhos mestiços Holandês-Zebu alimentados com níveis de glicerina bruta na dieta}

\author{
Ana Clara Bohnen de Barros²; João Restle ${ }^{3}$; Regis Luis Missio; \\ Fabrícia Rocha Chaves Miotto ${ }^{5}$; Wescley Faccini Augusto ${ }^{2}$; Raylon Pereira Maciel ${ }^{6}$; \\ Denise Adelaide Gomes Elejalde ${ }^{7}$ José Neuman Miranda Neiva ${ }^{5 *}$
}

\begin{abstract}
Assessment of carcass and meat characteristics of Holstein-Zebu crossbred young bulls finished in feedlot with crude glycerin levels $\left(0,60,120\right.$, and $240 \mathrm{~g} \mathrm{~kg}^{-1}$ dry matter) in replace of ground pearl millet grain and babassu mesocarp bran mixture-based diets. Twenty four bulls 30-month-old and initial average body weight of $390 \pm 31.5 \mathrm{~kg}$ were used. The animals were distributed in a completely randomized design with four treatments and six replicates. The absolute weight $(\mathrm{kg})$ of commercial cuts did not fit any of the tested regression models. However, the weight of the short ribs and the pistol cut were higher for animals fed with crude glycerin in relation to those fed without inclusion of this food in the diet. The proportion of the commercial cuts, however, was not changed. The increase of the crude glycerin levels linearly increased the proportion of carcass fat and reduced the muscle proportion, without changing the proportion of bone and the edible portion of the carcasses. The ratio muscle/fat reduced linearly with the advance of crude glycerin level of diets. The color of the meat, evaluated subjectively, increased linearly with the advance of crude glycerin levels of the diets, from dark red to slightly dark red. The texture, marbling, shear force, thawing loss and cooking loss were not changed by dietary levels of crude glycerin. The inclusion of up to $240 \mathrm{~g} \mathrm{~kg}^{-1}$ of crude glycerin in the diets increases the proportion of fat without changing the marketable portion of carcasses. The benefits to the meat quality refer to the improvement of color, without changing the other characteristics of economic interest.
\end{abstract}

Key words: Byproduct. Meat color. Glycerol. Marbling. Shear force.

\footnotetext{
1 Apoio financeiro do CNPQ.

2 Discentes, Curso de Mestrado do Programa de Pós-Graduação em Ciência Animal Tropical, Universidade Federal do Tocantins, UFT, Araguaína, TO, Brasil. E-mail: anaclarabohnen@hotmail.com; wescleyfaccini@hotmail.com

3 Bolsista PVNS Capes do Programa de Pós-Graduação em Ciência Animal Tropical, Escola de Medicina Veterinária e Zootecnia, UFT, Araguaína, TO, Brasil. E-mail: jorestle@terra.com.br

${ }^{4}$ Prof., Departamento de Agronomia, Universidade Tecnológica Federal do Paraná, UTFPR, Pato Branco, PR, Brasil. E-mail: regisluismissio@gmail.com

5 Profs., Escola de Medicina Veterinária e Zootecnia, Universidade Federal do Tocantins, UFT, Araguaína, TO, Brasil. E-mail: fabriciarchaves@hotmail.com; araguaia2007@gmail.com

${ }^{6}$ Discente, Curso de Doutorado do Programa de Pós-Graduação em Ciência Animal Tropical, Escola de Medicina Veterinária e Zootecnia, UFT, Araguaína, TO, Brasil. E-mail: raylonmaciel@yahoo.com.br

7 Bolsista de Pós-Doutorado, Programa de Pós-Graduação em Ciência Animal Tropical, Escola de Medicina Veterinária e Zootecnia, UFT, Araguaína, TO, Brasil. E-mail: denise.elejalde@gmail.com

* Author for correspondence
} 


\section{Resumo}

O estudo objetivou avaliar a composição física da carcaça e as características da carne de tourinhos alimentados com níveis de glicerina bruta $\left(0,120,240\right.$ e $360 \mathrm{~g} \mathrm{~kg}^{-1}$ de matéria seca) em dietas a base de grão de milheto moído e farelo do mesocarpo do babaçu. Foram utilizados 24 tourinhos mestiços HolandêsZebu com 30 meses de idade e $390 \pm 31,5 \mathrm{~kg}$ de peso corporal médio inicial. O delineamento experimental foi o inteiramente casualizado com quatro tratamentos e seis repetições. Os pesos absolutos $(\mathrm{kg}) \mathrm{dos}$ cortes comerciais não se ajustaram a nenhum dos modelos de regressão testados. Entretanto, verificouse que o peso da ponta de agulha e do traseiro especial foram maiores para os animais alimentados com glicerina bruta em relação àqueles alimentados sem inclusão deste alimento na dieta. A proporção dos cortes comerciais, no entanto, não foi alterada. A elevação do nível de glicerina bruta das dietas elevou linearmente a proporção de gordura das carcaças, reduzindo a proporção de músculo, mas não alterou a proporção de osso e a porção comestível das carcaças. A relação músculo/gordura foi reduzida linearmente com o avanço do nível de glicerina bruta das dietas. A coloração da carne, avaliada subjetivamente, aumentou linearmente com o avanço do nível de glicerina bruta das dietas, passando de vermelho escuro para vermelho levemente escuro. A textura, o marmoreio, a força ao cisalhamento das fibras musculares e a perda de líquidos ao descongelamento e cozimento não foram alteradas pelos níveis de glicerina bruta das dietas. A inclusão de até $240 \mathrm{~g} \mathrm{~kg}^{-1}$ de glicerina bruta na dieta de bovinos eleva a proporção de gordura, sem alterar a porção comercializável das carcaças. Os benefícios para a qualidade da carne se referem à melhora da coloração, sem alterar as demais características de interesse econômico.

Palavras-chave: Cor. Força ao cisalhamento. Glicerol. Marmoreio. Subproduto.

\section{Introduction}

Energy production is a strategic aspect in the socioeconomic development of Brazil. Biodiesel is one alternative source that can help to meet energy demand in a sustainable manner, and broaden and diversify the country's available energy resources. However, increased biodiesel production results in greater amounts of crude glycerin, the primary by product. This creates a need for new strategies for use of surplus crude glycerin not already utilized for the production of various products, mainly drugs, soaps, cosmetics, plastic, foods, and beverages (MOTA et al., 2009).

The use of crude glycerin in animal feeding has been the target of many research studies (FRANÇOZO et al., 2013; GÓRKA et al., 2013; MOREIRA et al., 2016a). Researchers have examined the use of this by-product in cattle feeding with regard to animal performance and carcass and meat quality, but results have been contradictory (LAGE et al., 2010; FRANÇOZO et al., 2013). In general, animal performance is expected to increase with the incorporation of crude glycerin because it improves energy-use efficiency, as observed by Moreira et al. (2016a). However, because the inclusion of crude glycerin in ruminant diets increases the rumen production of gluconeogenic precursors (CHANJULA et al., 2014), Pethick et al. (2004) suggested that total carcass fat and meat marbling are expected to increase. An increase in the carcass fat content can enhance the palatability and tenderness of the meat (WEBB; O'NEILL, 2008), as well as increase the weight of the most valued commercial cuts from the carcass (VAZ et al., 2012; MISSIO et al., 2015). This would increase loyalty within consumer markets and provide greater profitability to the industry.

The effect of crude glycerin on the productive performance of cattle seems to be independent of diet composition (HALES et al., 2013), among other factors. However, many studies have utilized crude glycerin in association with corn grain (LAGE et al., 2010; FRANÇOZO et al., 2013). Because alternative feedstuffs are sometimes used to replace corn grain when its price is high, the combination of crude glycerin with other feedstuffs should also be evaluated. Among feedstuffs to substitute 
corn grain at times when this commodity is found at high prices, millet grain and babassu mesocarp bran are noteworthy alternatives. The use of these feedstuffs in cattle diets has allowed the reduction of feed costs, with animal performance and carcass characteristics remaining similar to those obtained with corn grain (CRUZ et al., 2014, 2015; SILVA et al., 2014; ALENCAR et al., 2015).

The combination of crude glycerin, which is priced lower than corn grain, with these alternative feedstuffs could potentiate a further decrease in feed costs that would be extremely important if the carcass and meat quality are maintained. Moreira et al. (2016b) studied the association of crude glycerin with pearl millet grain and did not encounter detriments to the carcass or meat characteristics of the cattle. However, studies combining these three feedstuffs were not found in the current literature. Therefore, the present study aimed to evaluate both the physical composition of the carcass and the meat characteristics of young bulls consuming diets based on ground pearl millet grain and babassu mesocarp bran with various levels of crude glycerin.

\section{Material and Methods}

This study used 24 Holstein-Zebu crossbred young bulls (30 months old) with an initial average body weight of $390 \pm 31.5 \mathrm{~kg}$, distributed in a completely randomized experimental design, with four treatments (levels of crude glycerin in the diets) and six replicates (animals). The animals were kept in individual concrete floor stalls $\left(12 \mathrm{~m}^{2}\right)$ with troughs for food and water. At the beginning of the adaptation phase (14 days), all animals were dewormed and supplemented with vitamins A, D, and $\mathrm{E}$. Four diets with dry matter intake of $24 \mathrm{~g} \mathrm{~kg}^{-1}$ body weight (BW) were formulated according to the NRC (1996) to meet the requirements for growth and finishing. The diets included elephant grass silage as forage, as well as concentrates composed mainly of ground pearl millet grain, soybean meal, babassu mesocarp bran, and crude glycerin (Table 1). The four diets contained increasing levels of crude glycerin $\left(0,60,120\right.$, and $240 \mathrm{~g} \mathrm{~kg}^{-1} \mathrm{DM}$, representing $0 \%, 6 \%, 12 \%$, and $24 \%$ of the DM of the diets, respectively). A forage ratio of $20 \%$ was maintained across all treatment groups (Table 2).

Table 1. Chemical composition of ingredients ( $\mathrm{g} \mathrm{kg}^{-1}$ of DM).

\begin{tabular}{lcccc}
\hline Items & Silage & Pearl millet & BMB & Soybean meal \\
\hline Dry matter & 256.10 & 909.90 & 879.00 & 878.30 \\
Mineral matter & 74.10 & 19.30 & 57.50 & 65.70 \\
Crude protein & 37.70 & 113.40 & 29.60 & 393.50 \\
Ether extract & 15.40 & 41.90 & 8.50 & 16.10 \\
Neutral detergent fiber & 728.50 & 243.00 & 452.00 & 237.90 \\
Total carbohydrates & 872.80 & 825.40 & 904.40 & 524.70 \\
Non-fibrous carbohydrates & 144.30 & 630.20 & 452.40 & 296.80 \\
\hline
\end{tabular}

Silage $=$ elephant grass; $\mathrm{BMB}=$ babassu mesocarp bran .

The animals were confined for 96 days, including 14 days of adaptation to diet and stalls and 82 days of data collection. They were fed at $12 \mathrm{~h} 00$ ad libitum, and adjusted to allow 10\% orts of offered feed (dry matter basis). Animals fasting for 14-16 $\mathrm{h}$ were weighed at the beginning and end of the evaluation period. To obtain the average feed intake, feed and orts were weighed daily. On a weekly basis, samples of ingredients and orts from each animal, and ingredients of feed concentrates from mixture preparations were collected to provide representative samples. The samples were placed 
in plastic bags, labeled, and stored in a freezer at $-10^{\circ} \mathrm{C}$ until laboratory analysis.

Standard AOAC (1995) procedures were used to obtain the following components from the feed and orts samples: dry matter, mineral matter, crude protein, and ether extract. Neutral detergent fiber was determined according to the methodology of Van Soest et al. (1991). Total carbohydrates, nonfibrous carbohydrates, and total digestible nutrients were estimated as described by Sniffen et al. (1992), wherein: total carbohydrates $=1000$ - (crude protein + ether extract + mineral matter), non-fibrous carbohydrates $=1000$ - (total carbohydrates + neutral detergent fiber), total digestible nutrients $=$ digestible crude protein + (digestible ether extract $\times$ 2.25 ) + digestible neutral detergent fiber + digestible total carbohydrates. The metabolizable energy of diets was estimated considering $1 \mathrm{~kg}$ total digestible nutrients $=4.4 \mathrm{Mcal}$ digestible energy and $1 \mathrm{Mcal}$ of digestible energy $=0.82$ Mcal of metabolizable energy.

Table 2. Composition of the experimental diets.

\begin{tabular}{|c|c|c|c|c|}
\hline \multirow{2}{*}{ Item $\left(\mathrm{g} \mathrm{kg}^{-1}\right.$ of $\left.\mathrm{DM}\right)$} & \multicolumn{4}{|c|}{$\mathrm{g} \mathrm{kg}^{-1}$ of crude glycerin } \\
\hline & 0 & 60 & 120 & 240 \\
\hline \multicolumn{5}{|c|}{ Proximate composition } \\
\hline Elephant grass silage & 202.50 & 202.60 & 202.80 & 203.10 \\
\hline Ground millet grain & 343.90 & 313.80 & 283.70 & 223.20 \\
\hline Babassu mesocarp bran & 336.70 & 307.30 & 277.80 & 218.60 \\
\hline Crude glycerin & 0.00 & 59.10 & 118.40 & 237.60 \\
\hline Soybean meal & 87.80 & 87.80 & 87.90 & 88.00 \\
\hline Mineral mixture ${ }^{a}$ & 11.00 & 11.80 & 9.80 & 9.80 \\
\hline Urea & 4.60 & 6.40 & 8.10 & 11.50 \\
\hline Sodium chloride & 2.90 & 0.00 & 0.00 & 0.00 \\
\hline Ammonium sulfate & 0.50 & 0.60 & 0.80 & 1.10 \\
\hline Monensin sodium & 0.30 & 0.30 & 0.30 & 0.30 \\
\hline Virginiamycin & 0.20 & 0.20 & 0.20 & 0.20 \\
\hline \multicolumn{5}{|c|}{ Chemical composition } \\
\hline Dry matter, $\mathrm{g} \mathrm{kg}^{-1}$ as fed & 760.80 & 764.60 & 765.00 & 765.80 \\
\hline Mineral matter & 46.80 & 44.50 & 42.30 & 37.70 \\
\hline Crude protein & 104.07 & 104.85 & 105.39 & 106.38 \\
\hline Ether extract & 21.80 & 20.30 & 18.80 & 15.80 \\
\hline Neutral detergent fiber & 386.80 & 367.80 & 348.70 & 310.40 \\
\hline Total carbohydrates & 812.20 & 761.00 & 709.60 & 606.30 \\
\hline Non-fibrous carbohydrates & 425.50 & 393.20 & 360.80 & 295.90 \\
\hline Total digestible nutrients & 709.77 & 711.15 & 724.40 & 753.52 \\
\hline Metabolizable energy (Mcal kg-1 DM) & 2.56 & 2.57 & 2.61 & 2.72 \\
\hline
\end{tabular}

${ }^{a}$ Composition: P - 40 g; Ca - 146 g; Na - 56 g; S - 40 g; Mg - 20 g; Cu - 350 mg; Zn 1300 mg; Mn - 900 mg; Iron - 1050 mg; Co - 10 mg; I - 24 mg; Se - 10 mg; F (max.) 400 mg; excipient q.s. - 1000 mg; DM = dry matter.

The animals were slaughtered in a commercial slaughterhouse approved by the Brazilian Federal Inspection Service (Serviço de Inspeção Federal
- SIF). Prior to slaughter, the animals were fasted for 14-16 h. After slaughter, the carcasses were identified, divided in half, weighed, washed, and 
kept in a cold chamber for $24 \mathrm{~h}$ at a temperature varying between $0^{\circ} \mathrm{C}$ and $2^{\circ} \mathrm{C}$. The left half of the carcass was separated into primary cuts, with the forequarter separated from the pistol cut and short ribs between the $5^{\text {th }}$ and $6^{\text {th }}$ ribs, which included neck, shoulder, arm, and five ribs. Through the rib cut at $22 \mathrm{~cm}$ of the vertebral column, the pistol cut was separated from the short ribs, which included the ribs from the sixth rib onward, plus the abdominal muscles.

In the right half of the carcass, the $\mathrm{HH}$ section was removed according to the methodology of Hankins and Howe (1946). On the surface of the cranial portion of the $\mathrm{HH}$ section, after $30 \mathrm{~min}$ of exposure to air, the color was evaluated $(1=$ dark, $2=$ dark red, $3=$ slightly dark red, $4=$ red, and $5=$ bright red), texture ( $1=$ very coarse, $2=$ coarse, 3 $=$ slightly coarse, $4=$ thin, and $5=$ very thin), and marbling ( 1 to $3=$ traces, 4 to $6=$ light, 7 to $9=$ small, 10 to $12=$ medium, 13 to $15=$ moderate, and 16 to 18 = abundant) according to the method described by Müller (1987). In this same region, meat color also was measured in the CIE colorimetric system $\left(L^{*}, a^{*}, b^{*}\right)$ into four different sample points. The $\mathrm{HH}$ section was then dissected into muscle, fat, and bone, and weighed to estimate the proportion of each in the carcass (HANKINS; HOWE, 1946).

The longissimus dorsi muscle from the $\mathrm{HH}$ section was identified and frozen at $-18^{\circ} \mathrm{C}$. Three months later, a steak $2.5 \mathrm{~cm}$ thick was taken from each portion of the muscle, then identified, weighed, conditioned in aluminum trays, thawed for $12 \mathrm{~h}$ at $4{ }^{\circ} \mathrm{C}$ and weighed again to measure thaw loss. Afterwards, steaks were roasted in an oven until their internal temperature reached $70^{\circ} \mathrm{C}$. Cooked steaks were then chilled for $24 \mathrm{~h}$ at $4^{\circ} \mathrm{C}$. For each steak, shear force of the muscle fibers was measured using six extracted, cylinder-shaped cuts with an area of $1.0 \mathrm{~cm}^{2}$, cut perpendicular to the fiber direction in a Warner-Bratzler Shear machine.

The experimental design was completely randomized, with four treatments (levels of crude glycerin in the diets) and six replicates (animals). Shapiro Wilk and Cochran \& Bartlett's tests were performed, respectively, to evaluate the normality and homogeneity of variances, and whenever necessary, the data were transformed by $\log ^{2}$. Once we were satisfied with the assumptions of normality and homogeneity of variances, the data were subjected to analysis of variance and contrasts. The sum of squares of treatments in the contrasts analysis was decomposed into three contrasts: linear (0 - -10

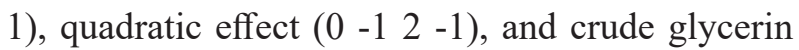
levels and diets with or without inclusion of crude glycerin (3 $-1 \quad-1 \quad-1)$. The general mathematical model is represented by $\mathrm{Y}_{\mathrm{ij}}=\mu+\mathrm{S} i+\mathrm{e}_{\mathrm{ij}}$, where $\mu$ $=$ overall mean, $\mathrm{S} i=$ the effect of the diets, and $\mathrm{e}_{\mathrm{ij}}$ $=$ residual random error. For probability of type I error, $\alpha=0.05$.

\section{Results and Discussion}

The absolute weights $(\mathrm{kg})$ of forequarter, short ribs and pistol cut did not fit $(\mathrm{P}>0.05)$ any of the regression models tested (Table 3). However, the short ribs and pistol cut of young bulls consuming crude glycerin was significantly heavier $(\mathrm{kg})(\mathrm{P}$ $<0.05)$ as compared to bulls whose diet did not include crude glycerin. This may be associated with the higher average daily gain (1.40 vs. $1.26 \mathrm{~kg}$ day $^{-1}$ ) for animals fed crude glycerin as compared to those fed diets without crude glycerin. Because the animals in this study were 30 months old, their sexual dimorphism was already completed. This may explain the lack of variation in the absolute weight of the forequarter. In this regard, the higher weight of short ribs and pistol cuts for bulls consuming glycerin is understandable, as these cuts gain weight later than the forequarter due to fat deposition occurring last in these cuts (MISSIO et al., 2015). Furthermore, according to Jorge et al. (1997), the muscles of the spine maintain a more marked growth as the animal ages, indicating that short ribs are the latest-maturing cut. Corroborating these assertions, Lawrence and Fowler (2005) 
mentioned that the animal body-growth waves begin from the extremities and move towards the axial skeleton and the loin.

The proportion of commercial cuts in relation to the cold carcass weight was not changed ( $P$ $<0.05)$ by the crude glycerin levels of the diets (Table 3). The results of this study disagree with those presented by Moreira et al. (2016b), who found that among the carcass primal cuts, only the forequarter weight $(\mathrm{kg}$ and $\%$ of the cold carcass weight) varied with the inclusion of crude glycerin $(0,6,12$, and 24\%) in pearl millet grain-based diets, and that it increased linearly, associated with an increase in average daily gain and manifestation of sexual dimorphism. The results of this current study are instead more similar to those obtained by Van Cleef et al. (2014), who did not find an alteration of the commercial primal cuts of the carcass of young Nellore bulls consuming levels of crude glycerin $(0 \%, 7.5 \%, 15 \%, 22.5 \%$, and $30 \%$ of dry matter) in corn-based diets, a finding that can be explained by the lack of variation in average daily gain. However, according to Berg and Butterfield (1976), the animal tends to maintain, within certain limits, a balance between the hindquarter and forequarter. This corroborates the results obtained in this study.

Table 3. Carcasses characteristics of Holstein-Zebu crossbred young bulls fed crude glycerin levels in the diets.

\begin{tabular}{|c|c|c|c|c|c|c|c|c|}
\hline \multirow{2}{*}{ Item } & \multicolumn{4}{|c|}{$\mathrm{g} \mathrm{kg}^{-1}$ of crude glycerin } & \multirow{2}{*}{$\begin{array}{l}\text { CV } \\
(\%)\end{array}$} & \multicolumn{3}{|c|}{ Contrasts, $p$ - Value } \\
\hline & 0 & 60 & 120 & 240 & & $\mathrm{~L}$ & Q & $0 v s . \mathrm{CG}$ \\
\hline \multicolumn{9}{|c|}{ Commercial cuts } \\
\hline Forequarter, $\mathrm{kg}$ & 50.23 & 53.35 & 51.52 & 53.07 & 8.80 & 0.440 & 0.650 & 0.096 \\
\hline Forequarter, \% & 40.85 & 40.38 & 39.50 & 41.08 & 3.38 & 0.754 & 0.060 & 0.416 \\
\hline Short ribs, $\mathrm{kg}$ & 13.72 & 15.25 & 15.15 & 14.73 & 7.16 & 0.253 & 0.650 & 0.003 \\
\hline Short ribs, \% & 11.16 & 11.51 & 11.67 & 11.45 & 5.36 & 0.480 & 0.215 & 0.208 \\
\hline Pistol cut, $\mathrm{kg}$ & 58.90 & 63.67 & 63.60 & 61.22 & 7.01 & 0.597 & 0.650 & 0.019 \\
\hline Pistol cut, $\%$ & 47.99 & 48.11 & 48.83 & 47.47 & 2.92 & 0.539 & 0.182 & 0.826 \\
\hline \multicolumn{9}{|c|}{ Physical composition } \\
\hline Muscle, $\mathrm{kg}$ & 160.22 & 167.43 & 164.45 & 160.89 & 9.09 & 0.871 & 0.645 & 0.574 \\
\hline Muscle, $\%$ & 65.21 & 63.29 & 63.12 & 62.35 & 2.63 & 0.016 & 0.224 & 0.010 \\
\hline Fat, $\mathrm{kg}$ & 48.18 & 57.29 & 58.11 & 60.72 & 4.79 & $<0.001$ & 0.645 & $<0.001$ \\
\hline Fat, \% & 19.61 & 21.66 & 22.3 & 23.53 & 8.86 & 0.002 & 0.279 & 0.005 \\
\hline Bone, $\mathrm{kg}$ & 38.39 & 41.14 & 39.66 & 38.47 & 7.75 & 0.735 & 0.645 & 0.363 \\
\hline Bone, $\%$ & 15.62 & 15.55 & 15.22 & 14.91 & 5.69 & 0.123 & 0.989 & 0.368 \\
\hline Muscle + Fat/bone & 5.43 & 5.46 & 5.61 & 5.76 & 7.16 & 0.102 & 0.999 & 0.324 \\
\hline Muscle/bone & 4.17 & 4.07 & 4.15 & 4.18 & 6.82 & 0.701 & 0.644 & 0.808 \\
\hline Muscle/fat & 3.33 & 2.92 & 2.83 & 2.65 & 11.9 & 0.004 & 0.211 & 0.005 \\
\hline
\end{tabular}

Muscle, $\%=64.57-0.010 \mathrm{CG}\left(\mathrm{R}^{2}=0,23\right)$; fat, $\mathrm{kg}=51.32+0.044 \mathrm{CG}\left(\mathrm{R}^{2}=0.70\right)$; fat, \% 20.18+0.015CG $\left(\mathrm{R}^{2}=0,34\right)$; muscle/fat $=3.23-0.003 \mathrm{CG}\left(\mathrm{R}^{2}=0.31\right) ; \mathrm{CV}=$ coefficient of variation; $\mathrm{L}=$ linear effect of crude glycerin level $(\mathrm{CG}) ; \mathrm{Q}=$ quadratic effect of crude glycerin level; 0 vs. $\mathrm{CG}=$ diets with vs. diets without crude glycerin.

The increase in the level of inclusion of crude glycerin in the diet did not change $(\mathrm{P}>0.05)$ the muscle weight $(\mathrm{kg})$ (Table 3 ), but reduced its proportion linearly in relation to the cold carcass weight. This decrease in the proportion of muscle was associated with a linear increase in the weight and proportion of fat tissue in the carcass as the level of crude glycerin in the diets was increased. 
The increased deposition of fat in the carcass may be associated with the fact that glycerol, the main component of crude glycerin, is fermented in the rumen to short-chain fatty acids, mainly propionate (DONKIN, 2008). The increased synthesis of these volatile fatty acids reduces the amount of available carbon and hydrogen for production of methane gas, improving digestibility and availability of energy to the animal (TRABUE et al., 2007; CHANJULA et al., 2014). Additionally, part of the glycerin is absorbed and metabolized in the liver due to its liquid form, allowing use of the glycerol for the gluconeogenesis (KREHBIEL, 2008). The increased availability of glucose elevates the blood insulin concentration, suggesting an increase in lipogenesis (MACH et al., 2009).

In the present study, weight and proportion of bone tissue in the carcasses did not change $(\mathrm{P}>$ $0.05)$ with increases in the crude glycerin levels of the diets (Table 3), indicating that deposition had already concluded for this tissue. These results are consistent with those discussed by Berg and Butterfield (1976), who mentioned that bone tissue has its greatest growth impulse in the youngest life stage of the animal, whereas muscle tissue has its greatest growth during the intermediate stage, and fat tissue is built primarily in a more advanced stage; further, bone tissue has the lowest variation in the animal body. The results of this study are also similar to those obtained by Bartoň et al. (2013) and Leão et al. (2013), who supplied levels of up to $10 \%$ and $24 \%$ of crude glycerin in cattle diets, respectively, and did not find alterations in the physical composition of the carcass. Similarly, Van Cleef et al. (2014) found that increases in the level of crude glycerin in diets for young Nellore bulls modified only the carcass fat content, which increased linearly.

The edible portion of the carcasses was not changed $(\mathrm{P}>0.05)$ by the increase in the amount of crude glycerin in the diets (Table 3). However, this increase linearly reduced the muscle/fat ratio, which is linked to the higher proportion of fat in the carcasses. These results demonstrate that the use of crude glycerin associated with ground pearl millet grain and babassu mesocarp bran does not compromise the edible portion of the carcasses, but it does produce meat with a larger proportion of fat. This can be exploited in markets that demand this characteristic. The results of the present study were partially similar to those found by Moreira et al. (2016b), who did not observe alterations in the edible portion or in the muscle/fat ratio of the carcass of young bulls fed pearl millet grain-based diets with levels of crude glycerin. It should be noted that different magnitudes in the expression of the muscle/fat ratio of carcasses between experimental trials can be expected, mainly due to variations in the composition of the diets, levels of energy and crude glycerin in the diets, animal body development stage at slaughter, and duration of the feeding period.

The meat color, evaluated subjectively, increased linearly with increases in the amount of crude glycerin in the diets, shifting from dark red in diets without glycerin, to slightly dark red in diets that included glycerin (Table 4). In contrast, the lightness $\left(\mathrm{L}^{*}\right)$, red intensity $\left(\mathrm{a}^{*}\right)$, and yellow intensity $\left(\mathrm{b}^{*}\right)$ indices, evaluated using a colorimeter, did not fit any of the regression models tested; however, these indices were higher in the meat from the animals consuming crude glycerin as compared with those fed diets without this by-product. The results of the present study were partially similar to those presented by Carvalho et al. (2014), who detected an increase in the $\mathrm{L}^{*}$ and $\mathrm{b}^{*}$ indices in the muscle when the crude glycerin level in the diets was increased from $0 \%$ or $6 \%$ to $12 \%$ or $18 \%$, respectively. This was attributed to the greater amount of ether extract in the muscle associated with these diets. Fat is lighter in color than the muscle, and thus its presence can contribute to increasing the lightness value (PEARCE et al., 2011). The lower a* index and color score of the meat from animals that did not consume crude glycerin may be associated with the lower availability of glucose, that when 
stored in the muscle as glycogen, might have inhibited the decline of muscle $\mathrm{pH}$ post-slaughter, resulting in a lower redox potential and formation of oxymyoglobin (ABRIL et al., 2001; MUCHENJE et al., 2009).

Additionally, when a higher muscle $\mathrm{pH}$ is maintained, the proteins in the meat are able to bind more strongly to water, resulting in less free water to reflect light and therefore, a darker appearance (PRICE; SCHWEIGERT, 1994; HUFFLONERGAN; LONERGAN, 2005). It should be noted that intact animals were used in this study, and these are more prone to stress, muscle glycogen reduction, and maintenance of a higher $\mathrm{pH}$ after slaughter (KUSS et al., 2010). Nevertheless, the meat color in the present study can be considered acceptable for the animal category utilized. Leão et al. (2013), in this context, did not find alterations in meat color, which varied from dark red to slightly dark red, in dairy crossbred steers receiving levels of crude glycerin $(0,60,120$, and $240 \mathrm{~g} \mathrm{~kg}^{-1}$ dry matter) and slaughtered at 30 months of age. Similarly, Egea et al. (2014) did not obtain alterations in the color of meat from cattle fed $0 \%, 4 \%$, and $6 \%$ crude glycerin, explained by the low levels of inclusion of this by-product in the diets. Françozo et al. (2013) and Eiras et al. (2014) also did not find alterations in the $\mathrm{L}^{*}, \mathrm{a}^{*}$, and $b^{*}$ indices of cattle fed up to $12 \%$ and $18 \%$ crude glycerin, respectively, attributed in part to the similar moisture content of the muscle.

Table 4. Meat characteristics of Nellore young bulls fed crude glycerin levels in the diets.

\begin{tabular}{|c|c|c|c|c|c|c|c|c|}
\hline \multirow{2}{*}{ Items } & \multicolumn{4}{|c|}{$\mathrm{g} \mathrm{kg}^{-1}$ of crude glycerin } & \multirow{2}{*}{$\begin{array}{l}\text { CV } \\
(\%)\end{array}$} & \multicolumn{3}{|c|}{ Contrasts, $\mathrm{p}$ - Value $^{1}$} \\
\hline & 0 & 60 & 120 & 240 & & $\mathrm{~L}$ & Q & 0 vs. $C G$ \\
\hline Color & 2.40 & 3.05 & 3.15 & 3.42 & 14,08 & $<0.001$ & 0.115 & $<0.001$ \\
\hline $\mathrm{L}^{*}$ & 34.75 & 37.19 & 37.44 & 37.53 & 5.23 & 0.102 & 0.395 & 0.009 \\
\hline$a^{*}$ & 18.17 & 20.99 & 21.98 & 20.85 & 9.71 & 0.164 & 0.074 & 0.004 \\
\hline$b^{*}$ & 7.06 & 8.68 & 9.30 & 8.67 & 15.43 & 0.168 & 0.103 & 0.007 \\
\hline Texture, points & 2.93 & 2.58 & 3.15 & 2.83 & 18.32 & 0.890 & 0.771 & 0,757 \\
\hline Marbling, points & 3.25 & 4.67 & 4.00 & 4.60 & 29.10 & 0.279 & 0.569 & 0.102 \\
\hline Shear force, $\mathrm{kgf} / \mathrm{cm}^{2}$ & 6.66 & 6.21 & 6.83 & 7.14 & 24.59 & 0.452 & 0.730 & 0.932 \\
\hline Thaw loss, $\%$ & 15.79 & 13.00 & 12.61 & 12.63 & 23.81 & 0.729 & 0.919 & 0.812 \\
\hline Cooking loss, $\%$ & 15.63 & 17.00 & 21.40 & 22.23 & 16.95 & 0.251 & 0.819 & 0.359 \\
\hline Total loss, $\%$ & 31.41 & 30.00 & 34.01 & 34.87 & 12.96 & 0.239 & 0.797 & 0.360 \\
\hline
\end{tabular}

Color, points $=2.607+0.0038 \mathrm{CG}\left(\mathrm{R}^{2}=0.41\right) ; \mathrm{L}^{*}=$ luminosity $(0=$ black and $100=$ white $)$; $\mathrm{a}^{*}=$ index from green $(-)$ to red $(+)$; $\mathrm{b}^{*}=$ index from blue $(-)$ to yellow $(+) ; \mathrm{CV}=$ coefficient of variation; $\mathrm{L}=$ linear effect of crude glycerin level $(\mathrm{CG}) ; \mathrm{Q}=\mathrm{quadratic}$ effect of crude glycerin level; 0 vs. $\mathrm{CG}=$ diets with $v s$. diets without crude glycerin.

In this study, the meat texture, marbling, shear force of the muscle fibers, loss of liquid from thawing and cooking, and total loss were not influenced $(\mathrm{P}>0.05)$ by the levels of crude glycerin in the diets (Table 4 ). These results are similar to those obtained by Moreira et al. (2016b), who evaluated similar crude glycerin levels to those of the present study in millet grainbased diets and did not find significant alterations in these meat parameters. Similarly, Leão et al. (2013) did not find alterations in texture, tenderness, marbling, liquid losses from thawing 
and cooking, or total liquid losses in meat from steers or cull cows fed increasing levels of crude glycerin in corn grain-based diets. Results of the present study are also similar to those presented by Françozo et al. (2013), who evaluated levels of crude glycerin $(0,5$, and $12 \%)$ in corn grain-based diets for young Nellore bulls in the feedlot, and did not find alterations in texture, shear force of the muscle fibers, marbling, or liquid losses from thawing and cooking.

Among the results presented here, the values obtained for the shear force of the muscle fibers stood out, averaging $6.71 \mathrm{kgf} / \mathrm{cm}^{2}$, characterizing the meat as tough. According to results presented by Miller et al. (2001), a shear force of $4.3 \mathrm{kgf} /$ $\mathrm{cm}^{2}$ is the point at which the consumer perceives the lower tenderness of the meat, and as this value is increased, the acceptability of the meat significantly decreases. The values obtained in this study may be related to the animal category, given that intact animals have a higher meat $\mathrm{pH}$ after slaughter (KUSS et al., 2010), less carcass fat cover (FREITAS et al., 2008), lower meat marbling (FREITAS et al., 2016), greater insoluble collagen content (DESTEFANIS et al., 2003), and higher muscle calpastatin (MICOL et al., 2009). On the other hand, the similar intramuscular fat content of the meat with higher crude glycerin levels in the diets was not expected, because, according to Pethick et al. (2004), meat marbling increases as the total carcass fat is increased. It is believed that marbling can increase with the inclusion of crude glycerin in the diet because the deposition of intramuscular fat has a preference for carbons originating from glucose and lactate, whereas the subcutaneous fat prefers carbon from acetate and acetyl units. However, the increase in meat marbling is not a common result in experiments with the use of crude glycerin in cattle diets, even when an increase is observed in the meat ether extract content (FRANÇOZO et al., 2013). This may be associated with, among other aspects, the level of sensitivity of the analysis performed to detect alterations in the deposition of intramuscular fat.

\section{Conclusion}

Inclusion of up to $240 \mathrm{~g} \mathrm{~kg}^{-1}$ crude glycerin in cattle diets increases the proportion of fat without changing the marketable portion of the carcasses. Benefits to the meat quality include improvement in color without changes in the other characteristics of economic interest.

\section{Acknowledgments}

We thank the Conselho Nacional de Pesquisa e Desenvolvimento Científico e Tecnológico (CNPq) for financial support.

\section{References}

ABRIL, M.; CAMPO, M. M.; ÖNENÇ, A. Beef colour evolution as a function of ultimate $\mathrm{Ph}$. Meat Science, Barking, v. 58, n. 1, p. 69-78, 2001.

ALENCAR, W. M.; RESTLE, J.; MISSIO, R. L.; NEIVA, J. N. M.; MIOTTO, F. R. C.; FREITAS, I. B. Feeding behavior and productive performance of steers fed millet grain-based diets, containing proportions of babassu mesocarp bran. Revista Brasileira de Zootecnia, Viçosa, v. 44, n. 12, p. 425-433, 2015.

ASSOCIATION OF OFFICIAL ANALYTICAL CHEMISTRY - AOAC. Official methods of analysis. $16^{\text {th }}$ ed. Arlington: AOAC International, 1995.

BARTOŇ, L.; BUREŠ, N, D.; HOMOLKA, P.; JANČÍK, F.; MAROUNEK, M.; ŘEHÁK, D. Effects of long-term feeding of crude glycerine on performance, carcass traits, meat quality, and blood and rumen metabolites of finishing bulls. Livestock Science, New York, v. 155, n. 1, p. 53-59, 2013.

BERG, R.T.; BUTTERFIELD, R. M. New concepts of cattle growth. $5^{\text {th }}$ ed. Sydney: Sydney University Press, 1976. $240 \mathrm{p}$.

CARVALHO, J. R. R.; CHIZZOTTI, M. L.; RAMOS, E. M.; MACHADO NETO, O. R.; LANNA, D. P. D.; LOPES, L. S.; TEIXEIRA, P. D.; LADEIRA, M. M. Qualitative characteristics of meat from young bulls fed different levels of crude glycerin. Meat Science, Barking, v. 96, n. 2, p. 977-983, 2014. 
CHANJULA, P.; PAKDEECHANUAN, P.; WATTANASIT, S. Effects of dietary crude glycerin supplementation on nutrient digestibility, ruminal fermentation, blood metabolites, and nitrogen balance of goats. Asian Australas Journal Animal Science, Seoul, v. 27, n. 3, p. 365-374, 2014.

CRUZ, R. S.; ALEXANDRINO, E.; MISSIO, R. L.; NEIVA, J. N. M.; RESTLE, J.; MELO, J. C.; PAULA NETO, J. J.; SILVA, D. P.; DUARTE, T. D.; SILVA, A. A. M. Características das carcaças e carne de tourinhos Nelore alimentados com níveis de concentrado e farelo do mesocarpo de babaçu. Arquivo Brasileiro de Medicina Veterinária e Zootecnia, Belo Horizonte, v. 67, n. 1, p. 299-308, 2015.

CRUZ, R. S.; ALEXANDRINO, E.; MISSIO, R. L.; RESTLE, J.; MELO, J. C.; PAULA NETO, J.; NEIVA, J. N. M.; MENDES FILHO, G. O.; SOUZA JÚNIOR, A.; DUARTE, T. T.; REZENDE, J. M.; SILVA, A. A. M. Desempenho bioeconômico de tourinhos alimentados com níveis de concentrado e farelo do mesocarpo de babaçu. Semina: Ciências Agrárias, Londrina, v. 35, n. 4, p. 2159-2174, 2014.

DESTEFANIS, G.; BRUGIAPAGLIA, M. T.; BARGE, C.; LAZZARONI, C. Effect of castration on meat quality in Piemontese cattle. Meat Sience, New York, v. 64, n. 2, p. 215-218, 2003.

DONKIN, S. S. Glicerol from biodiesel production: the new corn for dairy cattle. Revista Brasileira de Zootecnia, Viçosa, v. 37, p. 280-286, 2008. Suplemento Especial.

EGEA, M.; LINARES, M. B.; GARRIDOA, M. D.; VILLODRE, C.; MADRIDB, J.; ORENGO, J.; MARTÍNEZ, S.; HERNÁNDEZ, F. Crude glycerine inclusion in Limousin bull diets: animal performance, carcass characteristics and meat quality. Meat Science, Barking, v. 98, n. 4, p. 673-678, 2014.

EIRAS, C. E.; MARQUES, J. A.; PRADO, R. M.; VALERO, M. V.; BONAFÉ, E. G.; ZAWADZKI, F.; PEROTTO, D.; PRADO, I. N. Glycerine levels in the diets of crossbred bulls finished in feedlot: carcass characteristics and meat quality. Meat Science, Barking, v. 96, n. 2, p. 930-936, 2014.

FRANÇOZO, M. C.; PRADO, I. N.; CECATO, U.; VALERO, M. V.; ZAWADZKI, F.; RIBEIRO, O. L.; PRADO, R. M.; VISENTAINER, J. V. Growth performance, carcass characteristics and meat quality of finishing bulls fed crude glycerin-supplemented diets. Brazilian Archives of Biology and Technology, Curitiba, v. 56, n. 2, p. 327-336, 2013.
FREITAS, A. K.; RESTLE, J.; MISSIO, R. L.; PACHECO, P. S.; PÁDUA, J. T.; MIOTTO, F. R. C.; GRECO, L. F.; LAGE, M. E.; NEIVA, J. N. M. Carcass physical composition and physic-chemical characteristics of meat from Nellore cattle. Semina: Ciências Agrárias, Londrina, v. 37, n. 2, p. 1007-1016, 2016.

FREITAS, A. K.; RESTLE, J.; PACHECO, P. S.; PÁDUA, J. T.; LAGE, M. E.; MIYAGI, E. S.; SILVA, G. F. R. Características de carcaças de bovinos Nelore inteiros vs castrados em duas idades, terminados em confinamento. Revista Brasileira de Zootecnia, Viçosa, v. 37, n. 6, p. 1055-1062, 2008.

GÓRKA, P.; MCKINNON, J. J.; PENNER, G. B. Use of high-lipid by-product pellets as a partial replacement for barley grain and canola meal in finishing diets for beef steers. Canadian Journal of Animal Science, Ottawa, v. 93, n. 4, p. 523-528, 2013.

HALES, K. E.; BONDURANT, R. G.; LUEBBE, M. K.; COLE, N. A.; MACDONALD, J. C. Effects of crude glycerin in steam-flaked corn-based diets fed to growing feedlot cattle. Journal of Animal Science, Champaign, v. 91, n. 8, p. 3785-3780, 2013.

HANKINS, O. G.; HOWE, P. E. Estimation of composition of beef carcasses and cuts. Washington; USDA, 1946. 20 p. (Tecnical Bulletin USDA, 926).

HUFF-LONERGAN, E.; LONERGAN, S. M. Mechanisms of water-holding capacity of meat: the role of postmortem biochemical and structural changes. Meat Science, Barking, v. 71, n. 1, p. 194-204, 2005.

JORGE, A. M.; FONTES, C. A. A.; FREITAS, J. A.; SOARES, J. E.; RODRIGUES, L. R. R.; RESENDE, F. D. de; QUEIROZ, A. C. Rendimento da carcaça e de cortes básicos de bovinos e bubalinos, abatidos com diferentes estágios de maturidade. Revista Brasileira de Zootecnia, Viçosa, v. 26, n. 5, p. 1048-1054, 1997.

KREHBIEL, C. R. Ruminal and physiological metabolism of glycerin. Journal of Animal Science, Champaign, v. 86, p. 392, 2008. Supplement.

KUSS, F.; LÓPEZ, J.; RESTLE, J.; BARCELLOS, J. O.; MOLETTA, J. L.; PAULA LEITE, M. C. Qualidade da carne de novilhos terminados em confinamento e abatidos aos 16 ou 26 meses de idade. Revista Brasileira de Zootecnia, Viçosa, v. 39, n. 4, p. 924-931, 2010.

LAGE, J. F.; PAULINO, P. V. R.; PEREIRA, L. G. R.; VALADARES FILHO, S. C.; OLIVEIRA, A. S.; DETMANN, E.; PAIVA SOUZA, N. K.; LIMA, J. C. M. Glicerina bruta na dieta de cordeiros terminados em confinamento. Pesquisa Agropecuária Brasileira, Brasília, v. 45, n. 9, p. 1012-1020, 2010. 
LAWRENCE, T.; FOWLER, V. Growth of farm animals. London: CAB International, 2005. 330 p.

LEÃO, J. P.; NEIVA, J. N. M.; RESTLE, J.; MISSIO, R. L.; PAULINO, P. V. R.; MIOTTO, F. R. C.; SANTANA, A. E. M.; SOUSA, L. F.; ALEXANDRINO, A. Carcass and meat characteristics of different cattle categories fed diets containing crude glycerin. Semina: Ciências Agrárias, Londrina, v. 34, n. 1, p. 431-444, 2013.

MACH, N.; BACH, A.; DEVANT, M. Effects of crude glycerin supplementation on performance and meat quality of Holstein bulls fed high-concentrate diets. Journal of Animal Science, Champaign, v. 87, n. 2, p. 632-638, 2009.

MICOL, D.; OURY, M. P.; PICARD, B.; HOCQUETTE, J. F.; BRIAND, M.; DUMONT, R.; EGAL, D.; JAILLER, R.; DUBROEUCQ, H.; AGABRIEL, J. Effect of age at castration on animal performance, muscle characteristics and meat quality traits in 26-month-old Charolais steers. Livestock Science, New York, v. 120, n. 1-2, p. 116-126, 2009.

MILLER, M. F.; CARR, M. A.; RAMSEY, C. B.; CROCKETT, K. L.; HOOVER, L.C. Consumer thresholds for establishing the value of beef tenderness. Journal of Animal Science, Champaign, v. 79, n. 12, p. 3062-3068, 2001.

MISSIO, R. L.; RESTLE, J.; MOLETTA, J. L.; KUSS, F.; NEIVA, J. N. M.; ELEJALDE, D. A. G.; MOURA, I. C. F.; PRADO, I. N.; MIOTTO, F. C. R. Slaughter weights on animal performance, carcass commercial cuts and meat characteristics of cull cows. Semina: Ciências Agrárias, Londrina, v. 36, n. 6, p. 3827-3842, 2015.

MOREIRA, W. S.; MIOTTO, F. R. C.; RESTLE, R.; MISSIO, R. L.; NEIVA, J. N. M.; ELEJALDE, D. A. G.; PARENTE, R. R. P.; AUGUSTO, W. F. Physical composition of carcass, commercial cuts and meat characteristics of young bulls fed with crude glycerin levels in millet based-diets. Semina: Ciências Agrárias, Londrina, v. 37, n. 4, p. 2463-2476, 2016 b.

MOREIRA, W. S.; MIOTTO, F. R. C.; RESTLE, R.; MISSIO, R. L.; NEIVA, J. N. M.; MOREIRA, R. V. Crude glycerol levels in pearl millet-based diets for Nellore young bulls in feedlot. Revista Brasileira de Zootecnia, Viçosa, v. 45, n. 1, p. 32-38, 2016 a.

MOTA, C. J. A.; SILVA, C. X. A.; GONÇALVES, V. L. C. Gliceroquímica: novos produtos e processos a partir da glicerina de produção de biodiesel. Química Nova, São Paulo, v. 32, n. 3, p. 639-648, 2009.
MUCHENJE, V.; DZANA, K.; CHIMONYO, M.; STRYDOM, P. E.; HUGO, A.; RAATS, J. G. Some biochemical aspects pertaining to beef eating quality and consumer health: A review. Food Chemistry, New York, v. 112, n. 2, p. 279-289, 2009.

MÜLLER, L. Normas para a avaliação de carcaças e concurso de carcaças de novilhos. 2. ed. Santa Maria: Universidade Federal de Santa Maria, 1987. 31 p.

NATIONAL RESEARCH COUNCIL - NRC. Nutrient requirements of beef cattle. $7^{\text {th }}$ ed. rev. Washington: National Academy of Sciences, 1996. 242 p.

PEARCE, K. L.; ROSENVOLD, K.; ANDERSEN, H. J.; HOPKINS, D. L. Water distribution and mobility in meat during the conversion of muscle to meat and ageing and the impacts on fresh meat quality attributes - A review. Meat Science, Barking, v. 89, n. 2, p. 111-124, 2011.

PETHICK, D. W.; HARPER, G. S.; ODDY, V. H. Growth, developpment and nutritional manipulation of marbling in cattle: a review. Australian Journal Experimental Agriculture, Collingwood, v. 44, n. 7, p. 704-715, 2004.

PRICE, J. F.; SCHWEIGERT, B. S. Ciência de la carne y de los productos cárnicos. Zaragoza: Acribia, 1994. 581 p.

SILVA, A. H. G.; RESTLE, J.; MISSIO, R. L.; BILEGO, U. O.; FERNANDES, J. J. R.; REZENDE, P. L. P.; SILVA, R. M.; PEREIRA, M. L. R.; LINO, F. A. Milheto em substituição ao milho na dieta de novilhos confinados. Semina: Ciências Agrárias, Londrina, v. 35, n. 4, p. 2077-2094, 2014.

SNIFFEN, C. J.; O'CONNOR, J. D.; VAN SOEST, P. J.; FOX, D. G.; RUSSEL, J. B. A net carbohydrate and protein system for evaluating cattle diets: II. Carbohydrate and protein availability. Journal of Animal Science, Champaign, v. 70, n. 12, p. 3562-3577, 1992.

TRABUE, S.; SCOGGIN, K.; TJANDRAKUSUMA, S.; RASMUSSEN, M. A.; REILly, P. J. Ruminal fermentation of propylene glycol and glycerol. Journal of Agricultural and Food Chemistry, Washington, v. 55, n. 17, p. 7043-7051, 2007.

VAN CLEEF, E. H. C. B.; EZEQUIEL, J. M. B.; D’AUREA, A. P.; FÁVARO, V. R.; SANCANARI, J. B. I. D. Crude glycerin in diets for feedlot Nellore cattle. Revista Brasileira de Zootecnia, Viçosa, v. 43, n. 2, p. 86-91, 2014.

VAN SOEST, P. J.; ROBERTSON, J. B.; LEWIS, B. A. Methods for dietary fiber, neutral detergent fiber, and nonstarch polysaccharides in relation to animal nutrition. Journal of Animal Science, Champaign, v. 74, n. 10, p. 3583-3597, 1991. 
VAZ, F. N.; VAZ, R. Z.; PASCOAL, L. L.; PACHECO, P. S.; MIOTTO, F. R. C.; TEIXEIRA, N. P. Análise econômica, rendimentos de carcaça e dos cortes comerciais de vacas de descarte $5 / 8$ Hereford $3 / 8$ Nelore abatidas em diferentes graus de acabamento. Ciência Animal Brasileira, Goiânia, v. 13, n. 3, p. 338-345, 2012.
WEBB, H. A.; O’NEILL, H. A. The animal fat paradox and meat quality. Meat Science, Barking, v. 80, n. 1, p. 28-35, 2008. 